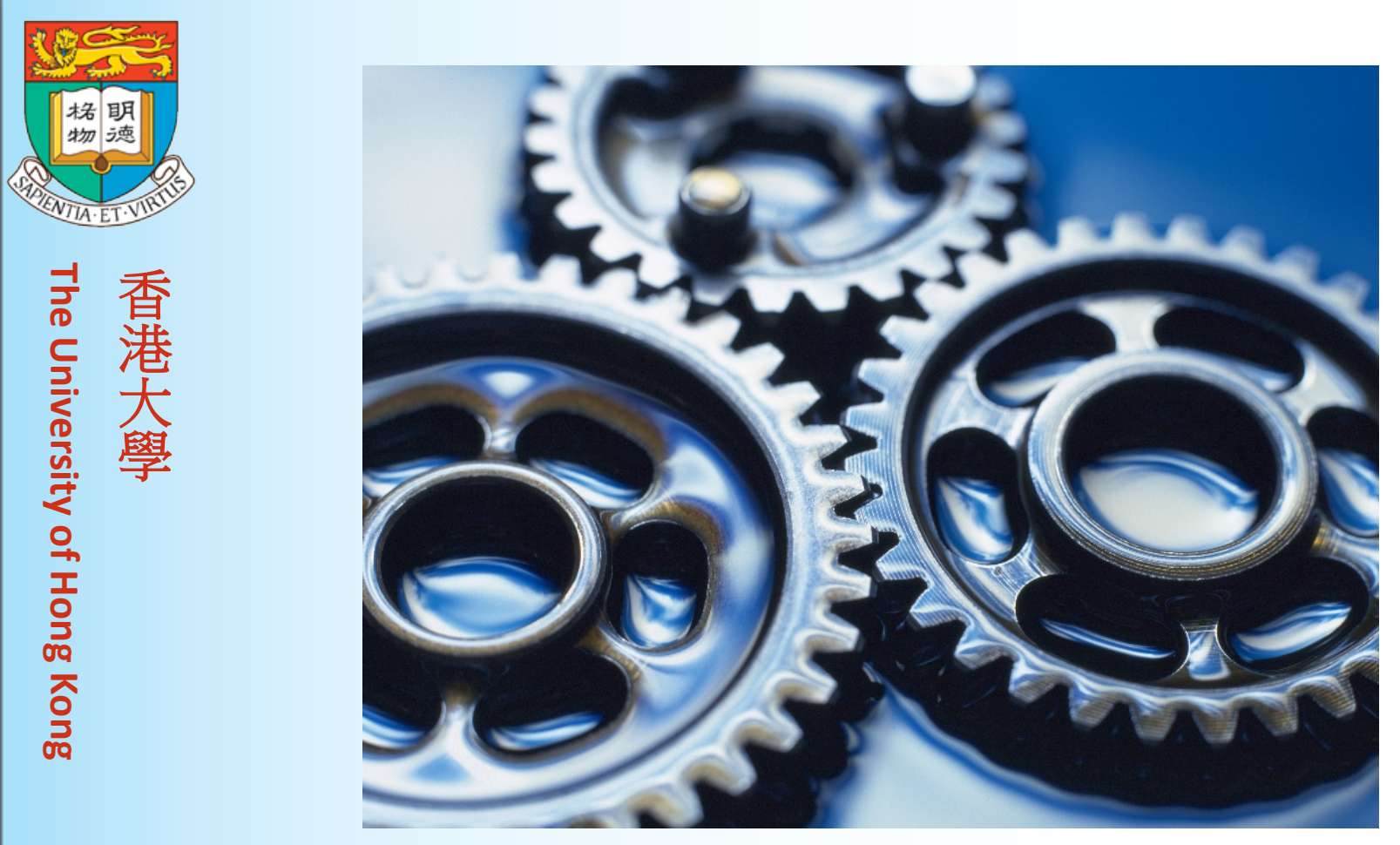

David T Palmer Eliot Liu

University of Hong Kong

China Open Access Week, 17 Oct 2016

\title{
Open E-Research in the HKU Scholars Hub
}

香港大学学术库中的开放E-Research 


\section{The HKU Scholars Hub - 香港大学学术库}

- 2005. IR

- 2009. HKU's Knowledge Exchange (KE)

- $3^{\text {rd }}$ mission, after Research \& Teaching

- Engage with the public for mutual benefit

- Libraries' grant proposal to enlarge the Hub to be,

- Vehicle for HKU KE

- Make visible and highlight HKU's research \& skill

- IR $\rightarrow$ Current Research Information System (CRIS)
- 2005. 机构典藏

- 2009. 香港大学知识交流

- 研究和教学之外的第三使命

- 与公众交流以获得共同利益

- 图书馆递交提案，以发展学术库为:

- 香港大学知识交流的工具

- 提高香港大学科研和技能的可见 度

- 机构典藏(IR) $\rightarrow$ 科研信息管理系统 (CRIS) 
- IR

- Fulltext publications

- OA, visibility, preservation
- 机构典藏

- 著作全文

- 开放获取、可见性、保存
- CRIS

- Research Objects: publications, researchers, projects, facilities...

- Visibility

- Decision support

- Optimisation of funding process

- TechTransfer

- Media resource

- 科研信息管理系统

一研究物件：著作、研究员、项 目、设备...

- 可见性

- 协助决策

- 优化资助过程

一技术转移

- 媒体资源 

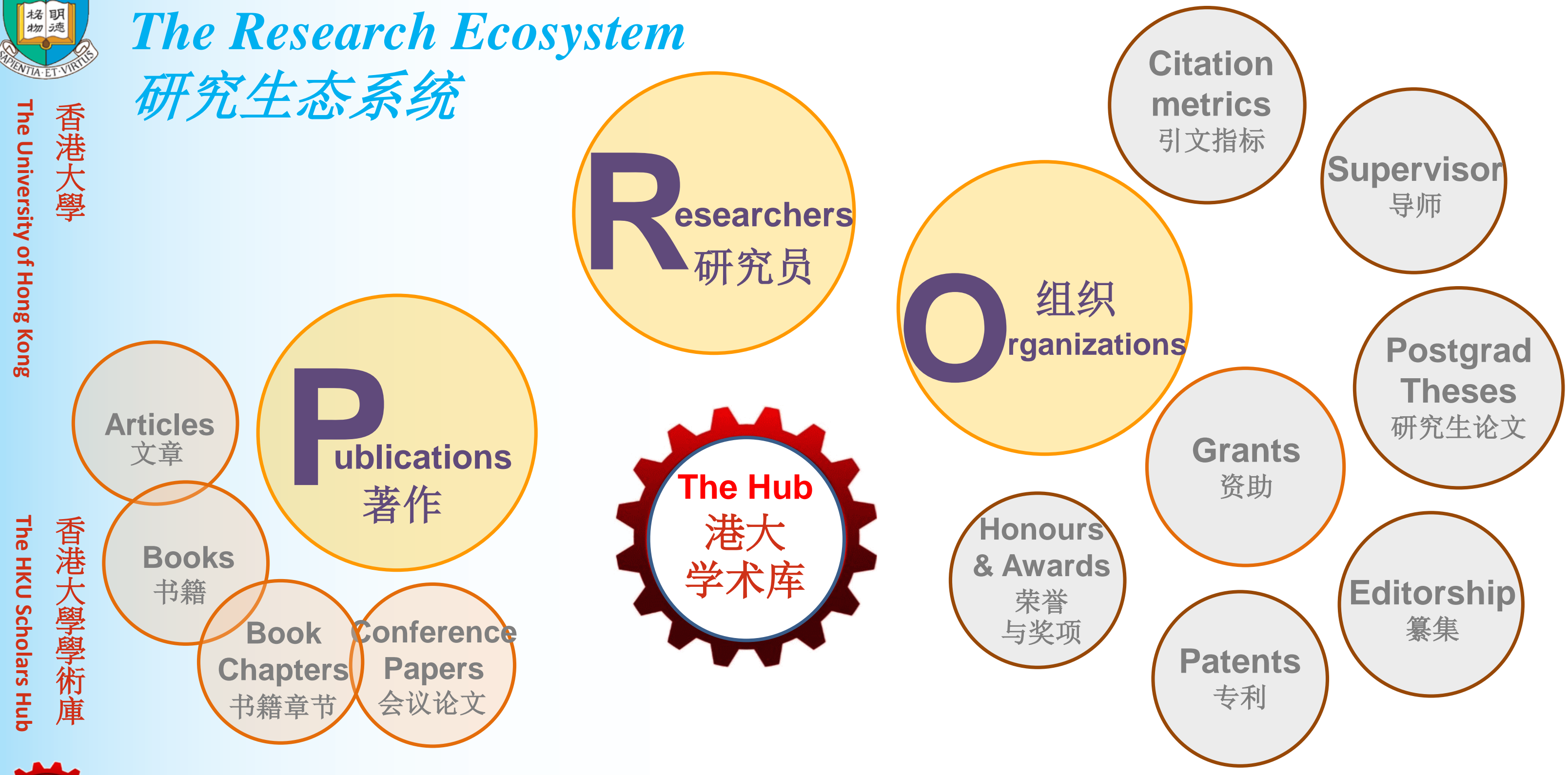

Adapted from: Yiu, ACH. (2016, July). HKU Scholars Hub: From IR to CRIS.

Presented at the 1st U21 Librarian Group Summit and University Library Pioneer Conference, Shanghai, China. 



\section{Open Science Taxonomy}

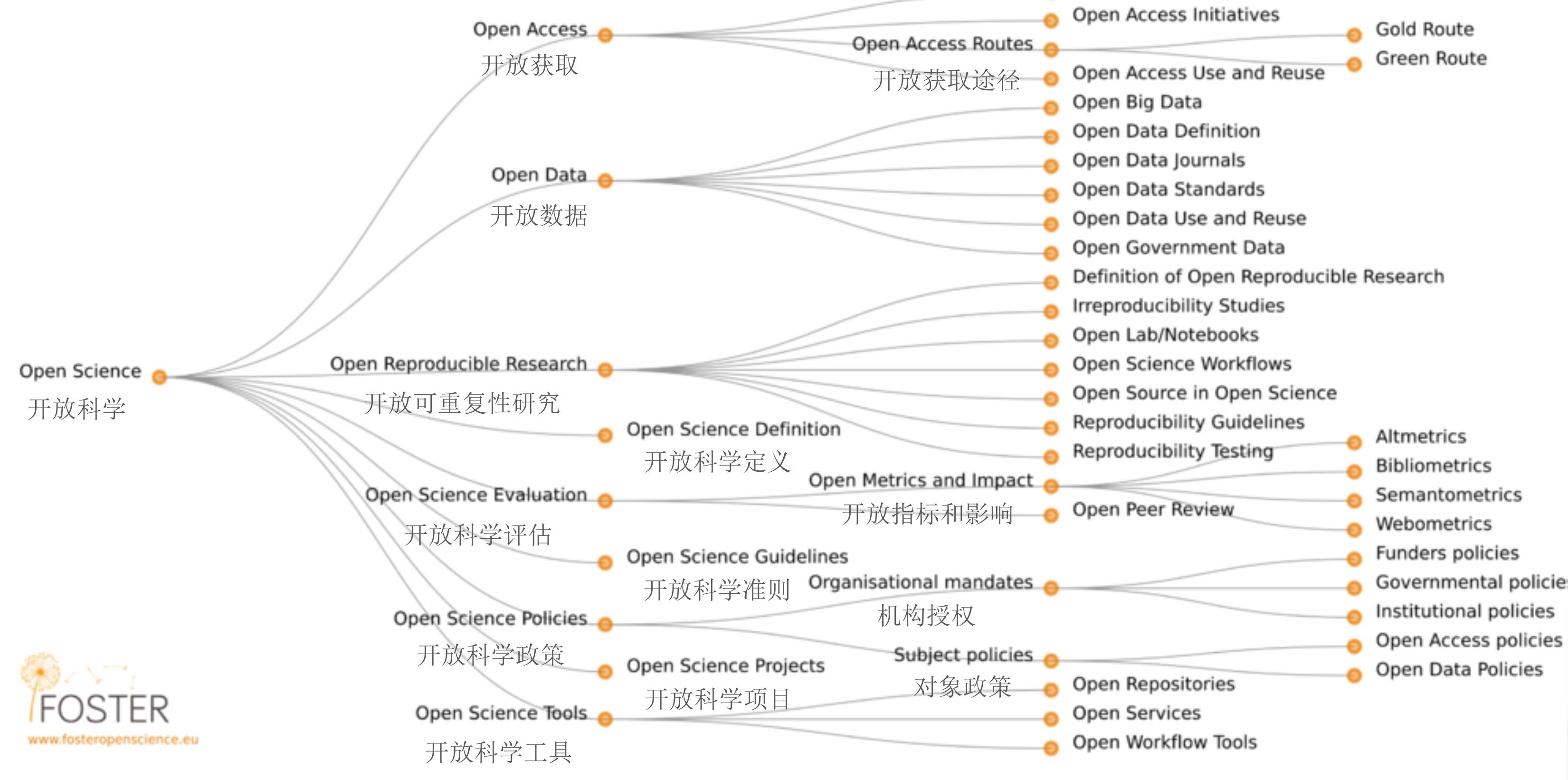

Open Access Definition

Open Access Initiatives

Open Access Use and Reuse

Gold Route

Open Big Data

Open Data Definition

Open Data Journals

Open Data Standards

Den Uata Use and Reuse

Irreproducibility Studies

Open Lab/Notebooks

Open Science Workflows

Open Source in Open Science

Reproducibility Guidelines

pen Science Definition

pen Science Evaluation 开放指标和影响

Open Peer Review

Bibliometrics

Semantometrics

Webometrics

Funders policies

Governmental policie

Institutional policies

Open Science Policies 几构授权

Open Science Projects
Open Science Tools $\begin{gathered}\text { 开放科学项目 对象政策 } \\ \text { 开放科学工具 }\end{gathered}$

Open Repositories

Open Workflow Tools 
Open Research. Open research makes clear

accounts of the methodology freely available via the

internet, along with any data or results extracted or

derived from them. This permits a massively

distributed collaboration, and one in which anyone

may participate at any level of the project.
开放研究。开放研究清晰描述了可 于网上自由获取的研究方法以及由此 产生的数据和结果。这使得大规模分 散式合作成为可能, 任何人可于项目 的任何阶段参与其中。
E-Research. The use of information technology to support existing and new forms of research. E-research extends eScience and cyberinfrastructure. Among the principle features, collaboration..
E-Research。利用信息技术支援现 有的以及新的研究形式。E-Research 拓展了eScience 和信息基础架构 (cyberinfrastructure), 最重要的特点之 一是合作.. 



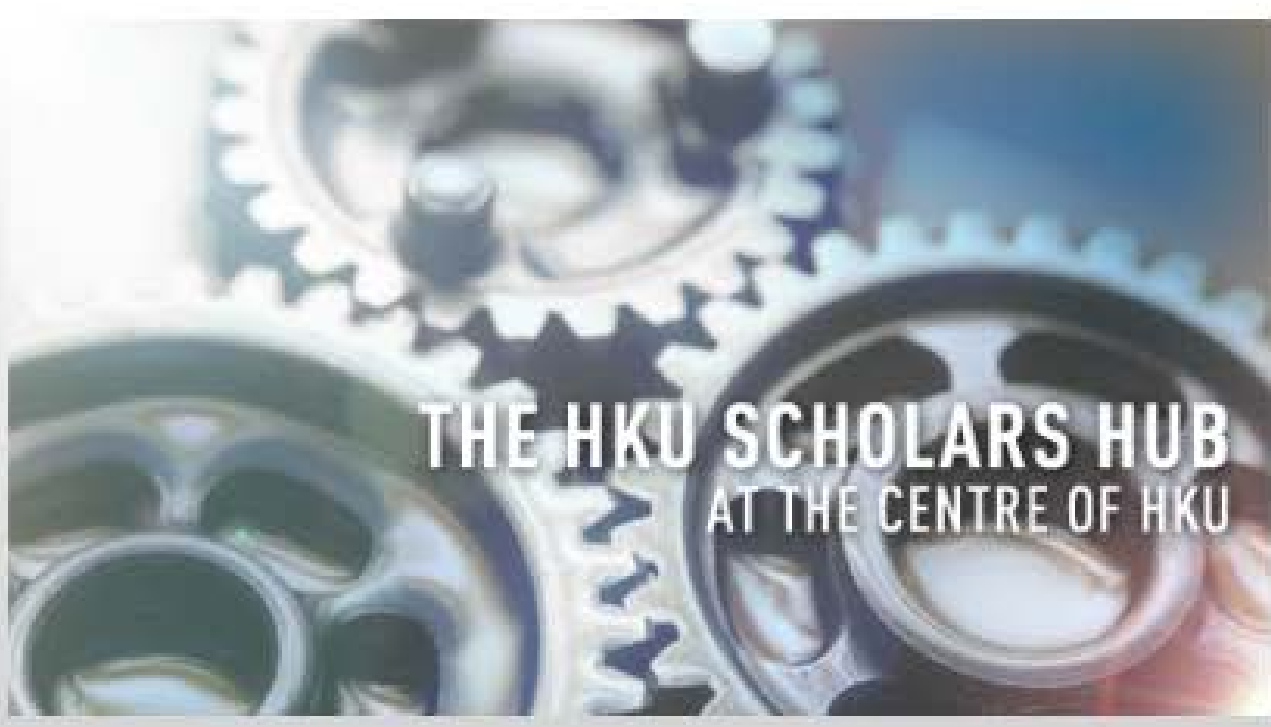

\section{Featured Scholar}

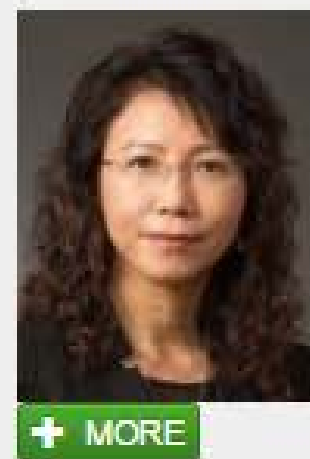

\section{Hub News}

ه

Professor Leung, Suet

Associate Dean (Research) Li Ka Shing Faculty of Medicine

- Clinical Professor

- Y M Kan Professorship in

Natural Sciences

- Professor, Chair of Gastrointestinal Cancer

Genetics and Genomics

- Associate Dean, Li Ka Shinq
Jul 2016: The Hub adds Datasets. New deposit page coming soon.

> Feb 2016: Updated to DSpace 5.2. Added global search capability under Quick Search tab.

> Jan 2016: The Hub is No. 1 in Asia and 41st worldwide, according to Webometrics.

> Apr 2015: Updated to DSpace 4.1, added mobile responsiveness.
The HKU Scholars Hub is the current research information system of The University of Hong Kong. As a key vehicle of HKU's Knowledge Exchange Initiative, The Hub aims to enhance the visibility of HKU authors and their research, and to foster opportunities for collaboration. 


\section{Leung, YMA}

\section{Profile}

- Contact Information

Professional Qualifications

Biography

Honours, Awards \& Prizes

Professional Societies

Major Research Themes \& Current

Projects

\section{Publications}

Selected Publications (10)

Articles (54)

Conference Papers (168)

Books (3)

Books Edited (2)

Book Chapters (2)

PG Theses (1)

Others (1)

\section{Datasets}

Datasets

Contact Information

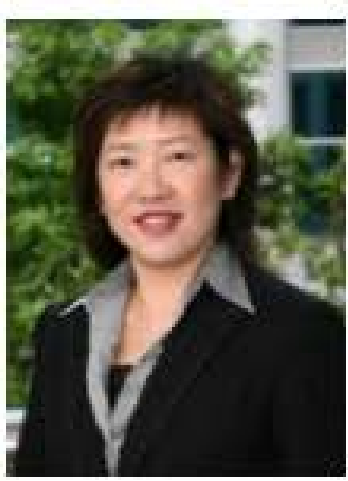

Tel: 28192630

Office:

FMA D
414

Dr Leung, Yee Man Angela 梁綺雯

Title:

Department:

Faculty:

Research Interests:(click to check for cognate researchers)

My URLs:

Also Cited As:
Associate Director

Sau Po Centre on Ageing

School of Nursing

Faculty of Social Sciences Li Ka Shing Faculty of Medic

- Health literacy and healt

- Chronic illness manage

- Service learning in ge

- Technology and agir

- Departmental pag

- http///orcid.org/0000-000 $\frac{1}{x-2}$

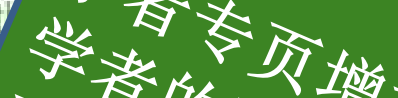

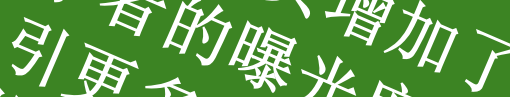

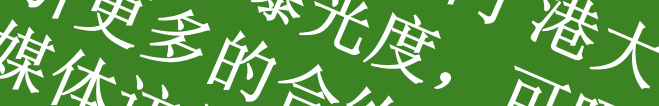

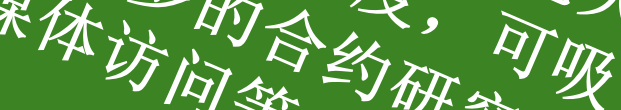
Leung, AYM Leung, $A$

Leung, Yee-man, Angela

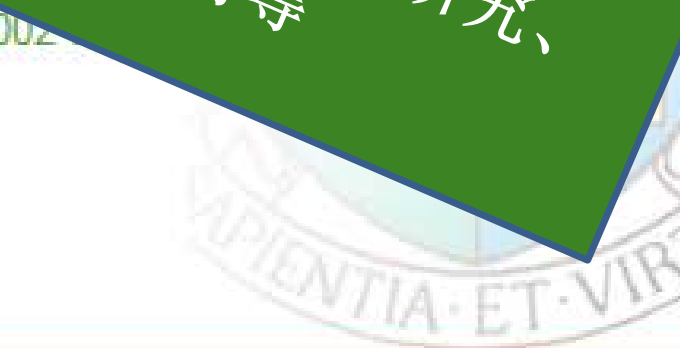
间 础食、 
\pm File Download

因 Content.pdf

Contact the author(s)

8. Links for fulltext

(May Require Subscription)

- Publisher Website: 10.1016/j.biocel.2014.09.002

- Scopus: eid_2-s2.0-84907467471

- PMID: 25220476

- Find via Find It GнкuL

- Supplementary

( Citations:

$$
\text { - Scopus: } 2
$$

Appears in Collections:

- Surgery: Journal/Magazine Articles

- Anatomy: JournalMagazine Articles

- President's Office: Journal/Magazine Articles

(Am) score 1

Tweeted by 1

See more details

1 readers on Mendeley
Article: Homeobox b5(Hoxb5) regulates the expression of Forkhead box D3 gene (Foxd3) in neural crest

Show simple item record Show full item record $\quad$ Export item record

Title Homeobox b5(Hoxb5) regulates the expression of Forkhead box D3 gene (Foxd3) in neural crest

Authors $\quad \begin{array}{ll}\text { Kam, MKM } \\ \text { Cheung, MCH } . \\ \text { Zhu, JJ } \\ \text { Cheng, WWC } \\ \text { Sat, EWY } \\ \text { Tam, PKH } \mathbf{9} \\ \text { Lui, VCH } \mathbf{9}\end{array}$

Issue $\quad 2014$

Date

Elsevier BV. The Journal's web site is located at http://www.elsevier.com/locate/biocel

The International Journal of Biochemistry \& Cell Biology, 2014, v. 55, p. 144-152 How to Cite? DOI: http://dx.doi.org/10.1016/j. biocel.2014.09.002

Abstract

Patterning of neural crest (NC) for the formation of specific structures along the anterio-posterior (A-P) body axis is governed by a combinatorial action of Hox genes, which are expressed in the neuroepithelium at the time of $\mathrm{NC}$ induction. Hoxb5 was expressed in $\mathrm{NC}$ at both induction and migratory stages, and our previous data suggested that Hoxb5 played a role in the NC development. However the underlving mechanisms by which Hoxb5 requlates the earlv NC develonment are largelv 
ISI Accession

WOS:000304864000018

Number ID

\section{Funding Agency}

Hong Kong Research Grants Council

Seed Funding Programme for Basic Research

University Grants Committee of Hong Kong

AOSPINE

\section{Funding Information:}

This work was supported by the Hong Kong Research Grants Council (HKU 775907M to PK-HT and HKU 765609 M to M-MG-B) and by the Seed Funding Programme for Basic Research (200910159040 and 200811159006 to M-MG-B and 200911159190 to SSC). Support was also received from the University Grants Committee of Hong Kong (AOE/M-04/04) and AOSPINE (AOSBRC-07-02 to DC). The funders had no role in study design, data collection and analysis, decision to publish, or preparation of the manuscript.

\section{References References in Scopus \\ Grants disease gene
Genetic dissection of Hirschsprung's disease
Developmental qenomics and skeletal research \\ Author Affiliations \\ 1. Shenzhen Children's Hospital \\ 2. The Centre for Applied Genomics University of Toronto \\ 3. The University of Hong Kong Li Ka Shing Faculty of Medicine \\ 4. China Medical University Shenyang \\ 5. Huazhong University of Science and Technology \\ 6. University of Toronto} $\underline{\text { Identification of functional variants in Neurequlin-1 (NRG1), a newly discovered Hirs }}$

\begin{tabular}{l} 
Grant Number \\
HKU 775907M \\
HKU 765609M \\
200910159040 \\
200811159006 \\
200911159190 \\
AoE/M-04/04 \\
AOSBRC-07-02 \\
\hline
\end{tabular}

\section{Grant Number}

AOSBRC-07-02 


\section{Li Ka Shing Faculty of Medicine}

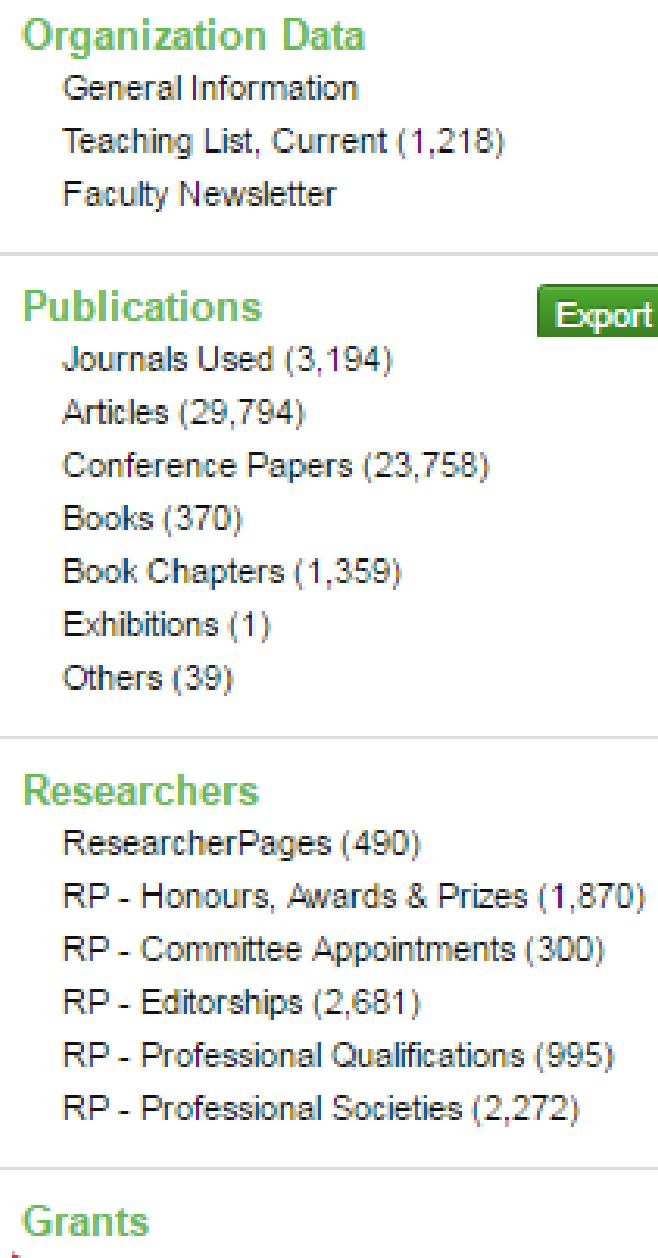

\section{Publications}

Journals Used $(3,194)$

Articles $(29,794)$

Conference Papers $(23,758)$

Books (370)

Book Chapters (1,359)

Exhibitions (1)

Others (39)

Grant - Current

Showing 1 to 10 of 1,075 entries

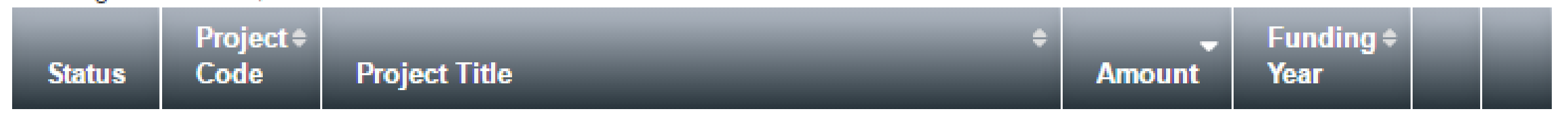

* $01121436 \quad$ Statistical method to identify risk genes of complex diseases based on functional gene sets and networks, with a genetic data mining application to hepatocellular carcinoma
Principal investigator
Co-Investigator
Dr Li, Miaoxin 2
Co-Investigator
Dr Kwan Sheung Him
Co-Investigator
Co-Investigator
Dr Jiang Deke
Co-Investigator
Professor Yu Long
Professor $\mathrm{Ng}$ Irene Oi Lin $\mathbf{2}$
Professor Sham Pak Chung $\mathbf{a}$

$*$

02132216 Genetic risks for chronic periodontitis: A genome-wide association study

999990

$2013 / 2014$
Principal investigator
Co-Investigator
Professor Leung, Wai Keung $\mathbf{3}$
Co-Investigator
Professor Cheah Kathryn Song Eng 2
Professor Chan Danny $\mathbf{a}$ 


\title{
New Program: Research Data Management (RDM)
}

\author{
新项目：研究数据管理
}

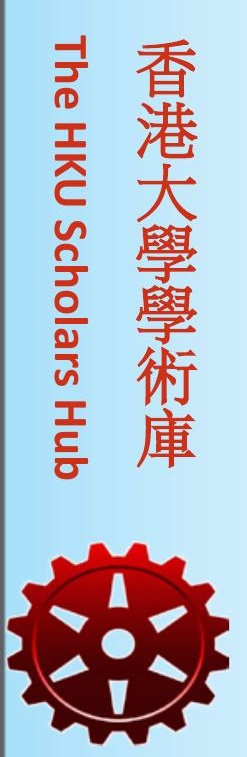



香港大学管理研究数据和记录的政策 $(2015)$

- Researchers (Staff \& students) are responsible for:

- Manage \& document data

- Depositing data

- University is responsible for:

- Providing facilities (data repository)

$>$ Integration with Hub publications, grants, authors

- Training, support, advice
- 研究员 (职员及学生) 的责 任 :

一管理及记录数据

- 存放数据

- 大学的责任 :

一提供设施 (数据典藏)

整合学术库的著作、 研究资助、作者

一培训、支援、建议 
Library responsible for infrastructure 图书馆需要提供基础设施

- Hardware \& software

- UI for deposit

- Indexing \& display of

稿 metadata

- Training, publicity, support
- 硬件和软件

- 存放界面

- 索引和显示元数据

- 培训、宣传、支援 


\section{Emphasis on "Responsible Research \& Integrity"}

\section{强调“可靠的研究和完整性”}

- Ethical data collection \& storage

- Human data: redaction?

- Prevention of data loss

- Replication datasets

- Proving research results if called upon

- Default access control: "restricted"

- Optional choice: public for re-sharing

- $1^{\text {st }} \mathrm{RDM}$ program in HK UGC schools From HKU $\rightarrow$ UGC-wide adoption Closed Data $\rightarrow$ Open Data
- 合乎道德准则的数据采集和存储

- 人员数据: 编校?

- 防止数据丢失

- 复制数据集

- 需要时提供研究结果

- 默认访问控制: “受限”

- 备用选择: 公众共享

- 为大学教育资助委员会 (教资会) 下属 院校中首先开展研究数据管理项目的学 校

港大 $\rightarrow$ 教资会其他院校

封闭数据 $\rightarrow$ 开放数据 


\section{Research Data Services - 研究數椖管理}

\section{Home}

RDM Planning

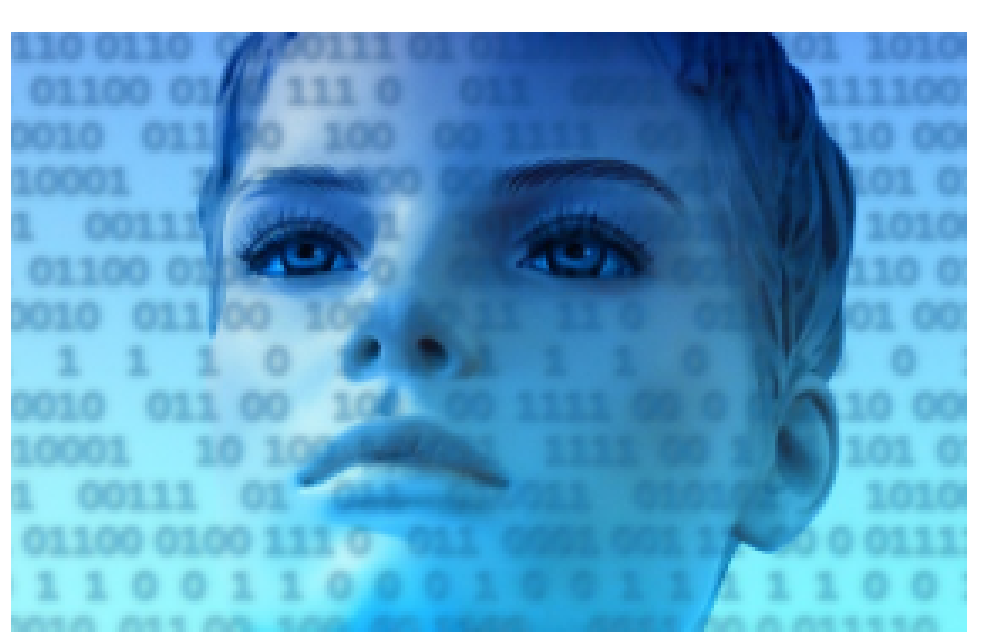

Help \& Support
Tools

\section{What is Research Data Management?}

HKU now requires RDM. RDM is a general term covering how you organize, structure, store, and care for the information used or generated during a research project. It includes the points below. The benefits of RDM, and the number now of funders, journals, and institutions requiring RDM are many and growing.

- Planning how your data will be collected, stored and cared for -- before, during, and after your research project -- many funders now require data management plans as part of applications. Many journals as a prerequisite to publishing an article, require underpinning datasets to be openly deposited.

- How you deal with information on a day-to-day basis over the lifetime of a project.

- What happens to data in the longer term - what you do with it after the project concludes.

\section{What Services can HKU Libraries Provide?}

The Libraries manage the HKU Scholars Hub which allows deposit
Quick Links

- Policy on the Management of Research Data \& Records

- Policy on Research Integrity

- Intellectual Property Rights Policy

- Institutional Review Board

- Human Research Ethics Committee

- Research Services

- Research

Ey tyate School 为很规

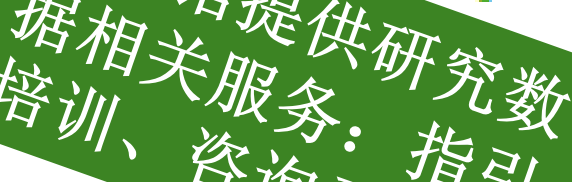

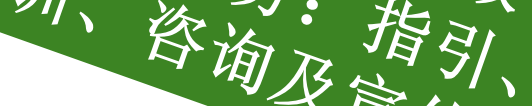




\section{Home} RDM Planning
Help \& Support
Tools
Contact Us

\section{Search}

\section{Research Data Management}

\section{Before Project}

Considerations (Copyright \& Ethical)

Data Management Plan

Documentation

Storage \& Backup

Find relevant data

During Project

After Project

\section{Data Management Plan (DMP)}

Many funders and journals now require DMPs. The 2015 HKU Policy on the Management of Research Records writes in paragraph 8, "[HKU] Researchers are responsible for: [..] developing and documenting clear procedures for the collection, storage, use, re-use, access and retention or destruction of the research data and records associated with their research. This include, where appropriate, defining protocols and responsibilities in a joint or multi-institution collaborative project. this information should be incorporated, where appropriate, in a research data management plan;"

A DMP is a digital document in which you describe what data you will collect during your research project, how you are going to store and mange the data during the project, and what whill happen to the data after the project is finished. The nature of your research project, data to be collected, and the requirements you need to fulfill will determine how you write your DMP.

\section{Points to be covered in a DMP}

- Description of the data to be collected / created in terms of format classification (eg. quantitative, qualitative, or sensitive)

- Standards / methodologies / metadata for data collection and mar 划

- Ethics and Intellectual Property concerns or restrictions to protect sensitur 金价

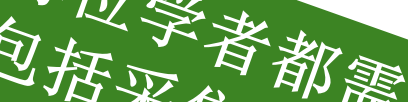
等，等他 including studv participant confidentialitv and intellectual provertv protection. 
- Optional deposit from October 2016

- Research postgraduate students: new requirement from Sep 2017, must deposit data with ethesis

- Academic staff:

- Plan for mandatory DMP with disbursement of RGC grant monies, summer of 2018

- From those grants, completion report will require evidence of data deposit
- 2016年10月开始以自愿形式存放数据

- 研究生：2017年9月开始必须存放电 子版毕业论文相关的研究数据

- 学术人员:

- 预计 2018年夏天开始利用研究资助 局的款项施行强制性的数据管理计 划

- 该款项要求数据存放证明的完整报告 


\section{Adding Dataset}

(For Open Data Access now. Procedures for Restricted Data will be added later.)

* For instructions, please visit, http:/lib.hku.hkiresearchdata/deposit_page.htm

\section{Toggle View}

\section{Titie *}

(If title is same as Journal Article, please add Data From

\section{Enter Title. \\ Add "Data From"}

Alternative Title

+ Add A New Alternative Title 


\section{昜 The HKU Scholars Hub 香港大學學術庫}

\section{Dataset}

File(s) held in the Hub

Files

Linked Publications

Linked Grants

Terms of Use

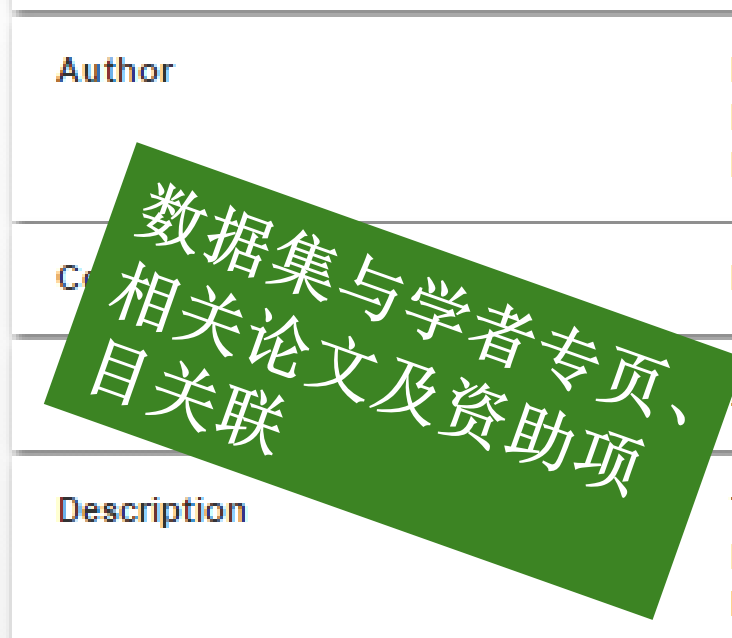

Bacon-Shone, John $\mathbf{2}^{1}$

Bolton, Kingsley ${ }^{2}$

Luke, Kang Kwong 2

Bacon-Shone, John ${ }^{1}$

2016-09-15

This study builds on the detailed empirical research of the three investigators, who have been collaborating on researching the Hong Kong linguistic situation since the early 1980s. This research utilises social survey methodology to investigate which

languages are used within the community. In more technical terms, this has involved carrying out 'sociolinguistic surveys' (surveys of languages in society) to investigate which languages are learnt, and which are used, by whom to whom, across a range of settings (or 'domains') in Hong Kong society. Previously, three such surveys have been conducted, in 1983, 1993, and 2003. The 1983 sociolinguistic survey used face- to-face interviews with a total of 1240 respondents (Bolton and Luke 1999). This was followed, in 1993 and 2003, by two telephone surveys conducted by the Social Sciences Research Centre of The University of Hong Kong, where a total of 886 respondents were interviewed in the 1993 survey, and 1060 in the 2003 (Bacon-Shone and Bolton 1998, 2008). One broad aim of all three surveys was to describe patterns of language acquisition, language use, and attitudes to language policies in Hong Kong. This study carried out a sociolinguistic survey of Hong Kong in 2014 together with detailed reanalysis of the 2011 census data across the 18 districts and 412 constituency areas, which yields useful and applicable results relating to ethnic/linguistic minorities, multilingualism, multiculturalism, and language planning, of direct interest to public policy in Hong Kong. It also calibrates for the first time, using expert assessment, self- reported claims of proficiency in oral English and Putonghua and written English and simplified Chinese. 摘要 此研究項目的三名負青人自一九八秀年代開始玨番港語言情况進 


\section{Dataset}

\section{File(s) held in the Hub}

Dataset Description

Files

Linked Publications

Linked Grants

Temis of Use 


\section{Dataset}

\begin{tabular}{l}
\hline Dataset Description \\
Files \\
Linked Public ations \\
Linked Grants \\
Terms of Use
\end{tabular}

\section{Citations}

Google Scholar: 2 Social Science

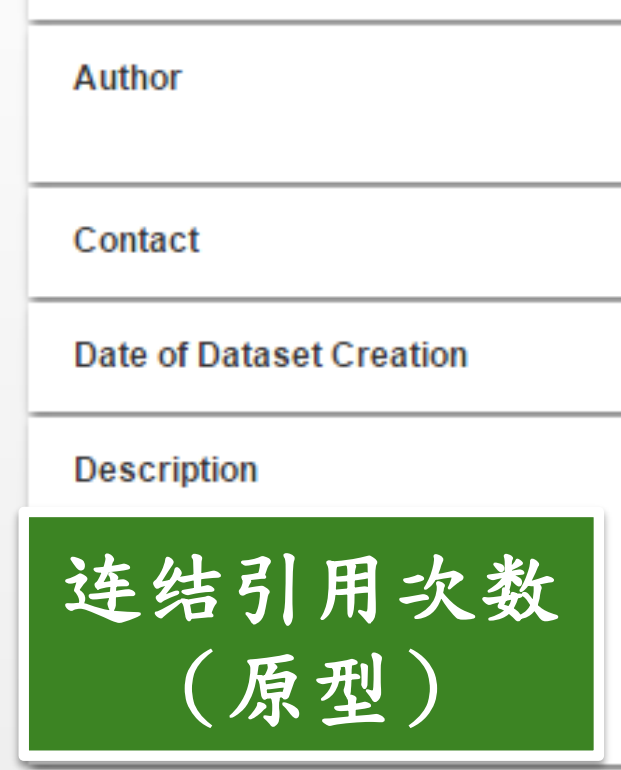

Citation

Liang, Hai

Fu, King-wa $\mathbf{a}^{1}$

\section{Fu, King-wa ${ }^{1}$}

\section{5-06-07}

Replication is an essential requirement for scientific discovery. The current study aims to generalize and replicate 10 propositions made in previous Twitter studies using a representative dataset. Our findings suggest 6 out of 10 propositions could not be replicated due to the variations of data collection, analytic strategies employed and inconsistent measurements. The replication data include 4 files: 1. EgoAlterProfiles (egos are randomly selected Twitter users; alters are the followers and followees of the egos) 2. EgoNetworks (all egos and their following relationships with alters) 3 . Exposure (the aggregated data for testing exposure hypothesis) 4. EgoTimelines (all tweets information posted by egos) All datasets have been anonymized. 


\section{All citations \\ Testing propositions derived from Twitter studies: generalization and replication in \\ Articles computationa...}

Case law

My library

\section{Any time}

Since 2016

Since 2015

Since 2012

Custom range...

Sort by relevance

Sort by date

$\checkmark$ include patents

$\checkmark$ include citations

$\square$ Search within citing articles

Privacy protection and self-disclosure across societies: A study of global Twitter

Find It@HKUL users

H Liang, F Shen, K Fu - New Media \& Society, 2016 - nms.sagepub.com

Abstract Privacy is a culturally specific phenomenon. As social media platforms are going

global, questions concerning privacy practices in a cross-cultural context become

inc reasingly important. The purpose of this study is to examine cultural variations of ...

Related articles Cite Save

Probing the Limits of Social Data

[PDF] epfl.ch

A Olteanu - 2016 - infoscience.epfl.ch

Abstract Online social data has been hailed to provide unprecedented insights into human phenomena due to its ability to capture human behavior at a scale and level of detail, both in breadth and depth, that is hard to achieve through conventional data collection techniques ... Related articles Cite Save More 


\section{Open Research: Benefits}

\section{开放研究: 优势}

- OA benefits amplified with OR

- Greater discovery, readership \& citations

- Greater public engagement

- Faster Impact

- Wider Collaboration

- Increased interdisciplinary conversation

- Increased business opportunities

- And,

- OR will make research results more reproducible \& transparent
- 开放研究扩大了开放获取的优势

- 增加曝光度、阅读量及引用次

- 增加公众参与

- 更快产生影响力

- 更广泛的合作

- 增加跨学科的交流

- 增加商业机会

- 以及,

- 开放研究可以增加研究成果的 可重复性和透明度 



\section{References 参考书目}

- Liu, E., \& Palmer, D. T. (2015). The HKU Scholars Hub - Beyond an institutional repository [香港 大學學術庫——機構知識庫的應用擴展]. Journal of Academic Libraries [大學圖書館學報], 4, 68-75. Available at http://hub.hku.hk/handle/10722/219961

- Palmer, D. T., Bollini, A., Mornati, S., \& Mennielli, M. (2014). DSpace-CRIS@ HKU: Achieving visibility with a CERIF compliant open source system.Procedia Computer Science, 33, 118-123. doi: http://dx.doi.org/10.1016/j.procs.2014.06.019; also available at http://hub.hku.hk/handle/10722/198431

- Yiu, A.C.H. (2016, July). HKU Scholars Hub: From IR to CRIS. Presented at the 1st U21 Librarian Group Summit and University Library Pioneer Conference, Shanghai, China. Available at http://hub.hku.hk/handle/10722/226796 


\section{Acknowledgement}

- The authors would like to thank the HKU Scholars Hub team for their dedicated work and concerted effort in improving the Hub.

- This PPT \& PDF are licensed under the Creative Commons Attribution "CC-BY" license. This license permits use of this work, so long as attribution is given. For more information about the license, visit http://creativecommons.org/licenses/by/3.0/

- Archived at http://hub.hku.hk/handle/10722/233946

\section{David T Palmer}

\$ http://hub.hku.hk/cris/rp/rp00001

(10) http://orcid.org/0000-0001-5616-4635
Eliot Liu

(16) http://orcid.org/0000-0002-4862-2373 